\title{
PENGARUH LEVERAGE OPERASI, LEVERAGE KEUANGAN DAN \\ LEVERAGE TOTAL TERHADAP RISIKO SISTEMATIS SAHAM \\ PADA PERUSAHAAN MANUFAKTUR YANG TERDAFTAR DI BEI \\ PERIODE SEBELUM DAN SESUDAH KONVERGENSI IFRS
}

\author{
Septi Ika Pawestri \\ Alumni Program Studi Akuntansi Universitas negeri Yogyakarta \\ septi.ika29@yahoo.com \\ Ratna Candra Sari \\ Jurusan Pendidikan Akuntansi Universitas Negeri Yogyakarta
}

\begin{abstract}
Abstrak: Pengaruh Leverage Operasi, Leverage Keuangan, dan Leverage Total terhadap Risiko Sistematis Saham pada Perusahaan Manufaktur yang Terdaftar di BEI Periode Sebelum dan Sesudah Konvergensi IFRS. Penelitian ini bertujuan untuk mengetahui (1) pengaruh leverage operasi, leverage keuangan, leverage total terhadap risiko sistematis saham, (2) perbedaan pengaruh leverage operasi, leverage keuangan, dan leverage total terhadap risiko sistematis saham dan (3) perbedaan tingkat risiko sistematis saham pada perusahaan manufaktur yang terdaftar di BEI periode sebelum dan sesudah konvergensi IFRS. Teknik pengumpulan data yang digunakan dalam penelitian ini adalah teknik dokumentasi. Teknik analisis data yang digunakan dalam penelitian ini adalah analisis regresi linear sederhana dan uji dua pihak t-test. Hasil penelitian menunjukkan bahwa leverage operasi berpengaruh negatif dan tidak signifikan terhadap risiko sistematis saham sebelum dan sesudah konvergensi IFRS. Leverage keuangan berpengaruh positif dan tidak signifikan terhadap risiko sistematis saham sebelum konvergensi IFRS sedangkan variabel leverage keuangan berpengaruh negatif dan tidak signifikan terhadap risiko sistematis saham sesudah konvergensi IFRS. Leverage total tidak berpengaruh terhadap risiko sistematis saham sebelum konvergensi IFRS dan variabel leverage total berpengaruh positif dan tidak signifikan terhadap risiko sistematis saham sesudah konvergensi IFRS. Tidak terdapat perbedaan pengaruh leverage operasi, leverage keuangan dan leverage total terhadap risiko sistematis saham sebelum dan sesudah konvergensi IFRS. Tidak terdapat perbedaan tingkat risiko sistematis saham antara sebelum dengan sesudah konvergensi IFRS.
\end{abstract}

Kata kunci: Risiko Sistematis Saham, Leverage Operasi, Leverage Keuangan, Leverage Total

\begin{abstract}
The Effect of Operating Leverage, Financial Leverage, and Total Leverage on Systematic Risk of Manufacturing Companies Listed in Indonesian Stock Exchange Before and After Convergension of IFRS. This research aims to determine (1) the effect of operating leverage, financial leverage, total leverage on systematic risk, (2) the differences in the effect of operating leverage, financial leverage, and total leverage on systematic risk and (3)the differences of systematic risk of manufacturing companies listed in Indonesia Stock Exchange before and after the IFRS convergence period. The data collection technique was documentation techniques. Method used in analyzing data that are simple linear regression and t-test. The results of this study indicate that operating leverage have insignificant negative effect on the systematic risk before and after IFRS convergence. Financial leverage has insignificant positive effect on the systematic risk before IFRS convergence and financial leverage has insignificant negative effect on the systematic risk after IFRS convergence. Total leverage has no effect on the systematic risk before IFRS convergence and total leverage has insignificant positive effect on the systematic risk after IFRS convergence. There were no difference effect of operating leverage, financial leverage and total leverage on systematic risk before and after IFRS convergence. There was no difference between the level of systematic risk before and after IFRS convergence.
\end{abstract}




\section{JURNAL NOMINAL / VOLUME III NOMOR 1 / TAHUN 2014}

Keywords: Systematic Risk, Operating Leverage, Financial Leverage, Total Leverage

\section{PENDAHULUAN}

Investasi merupakan penundaan konsumsi sekarang untuk dimasukkan ke aktiva produktif selama periode waktu tertentu (Jogiyanto, 2010: 5).. Salah satu bentuk investasi aktiva produktif dalam bentuk aktiva keuangan adalah investasi langsung di pasar modal yang berupa saham (Jogiyanto, 2010: 5-7).

Saham sendiri bukanlah salah satu instrumen pasar modal yang bebas risiko. Setiap investasi dalam pasar modal terutama pasar saham memiliki risiko dimana setiap aset memiliki tingkat risiko yang berbedabeda. Salah satu risiko yang perlu diperharikan investor adalah risiko pasar (risiko sistematis atau risiko yang tidak dapat didiversifikasi) yang mencerminkan risiko penurunan pasar saham secara umum yang tidak dapat dihilangkan oleh diversifikasi (Brigham dan Houston, 2012: 322).

Risiko suatu aset dipengaruhi oleh berbagai faktor. Faktor yang mempengaruhi risiko dibagi menjadi faktor fundamental makro (eksternal) dan faktor fundamental mikro (internal). Faktor fundamental makro dalam istilah analisis pasar modal disebut dengan faktor fundamental negara, faktor ini bersifat uncontrollable sehingga tidak dapat dikendalikan perusahaan. Faktor fundamental makro meliputi faktor-faktor: (1) ekonomi, (2) sosial, budaya, demografi dan lingkungan, (3) kekuasaan politik, pemerintahan, dan hukum, (4) teknologi, dan (5) persaingan (David, F. R, dalam Bambang dan Cahyani, 2009: 66). Sedangkan faktor fundamental mikro dapat berupa leverage operasi dan leverage keuangan yang mempengaruhi tingkat risiko perusahaan secara keseluruhan.

Leverage operasi merupakan tingkat sejauh mana perusahaan menggunakan biaya-biaya tetap dalam operasi perusahaan. Leverage operasi merupakan salah satu faktor yang mempengaruhi risiko bisnis. Risiko bisnis dalam artian berdiri sendiri adalah suatu fungsi dari ketidakpastian yang inheren di dalam proyeksi pengembalian atas modal yang diinvestasikan di dalam sebuah perusahaan (Brigham dan Houston, 2006: 9-12). Salah satu potensi pengaruh leverage operasi adalah perubahan dalam volume penjualan akan menghasilkan perubahan yang lebih dari proporsional dalam laba (atau) rugi operasional (Horne dan Wachowicz, 2007: 182). Penggunaan biaya tetap yang tinggi (leverage operasi tinggi), bahkan penurunan penjualan yang kecil sekalipun dapat menyebabkan terjadinya penurunan return on equity (ROE) yang cukup besar. ROE merupakan 


\section{JURNAL NOMINAL / VOLUME III NOMOR 1 / TAHUN 2014}

alat ukur risiko bisnis sehingga penurunan ROE yang besar menunjukkan peningkatan risiko bisnis. Hubungan leverage operasi dan risiko bisnis jika hal-hal lain dianggap konstan, semakin tinggi leverage operasi sebuah perusahaan, semakin tinggi risiko bisnis. Suatu tindakan yang meningkatkan risiko bisnis akan meningkatkan risiko sistematis saham (Brigham dan Houston, 2006: 11). Oleh karena itu, besarnya leverage operasi mempengaruhi besarnya risiko sistematis saham.

Risiko yang dibebankan kepada para investor tidak hanya risiko bisnis, namun ada risiko keuangan. Risiko keuangan merupakan peningkatan atau tambahan risiko yang ditanggung oleh pemegang saham, di atas risiko bisnis dasar perusahaan yang diakibatkan oleh penggunaan leverage keuangan. Leverage keuangan merupakan tingkat sejauh mana sekuritas dengan utang digunakan dalam struktur modal sebuah perusahaan. Pendanaan melalui utang memiliki tingkat risiko yang cukup tinggi karena sangat dipengaruhi faktor-faktor internal perusahaan misalnya kondisi keuangan perusahaan dan faktor eksternal perusahaan misalnya tingkat suku bunga (Brigham dan Houston, 2006: 17-19). Perubahan dalam penggunaan utang akan menyebabkan terjadinya perubahan pada laba per lembar saham (earning per shareEPS) dan nantinya akan menyebabkan perubahan pada risiko yang ditanggung oleh pemegang saham.

Risiko bisnis dan risiko keuangan akan memperbesar besarnya risiko yang ditanggung oleh pemegang saham. Dapat diartikan bahwa kombinasi leverage operasi dan leverage keuangan yang merupakan salah satu faktor yang mempengaruhi risiko bisnis dan risiko keuangan atau disebut dengan leverage total mempengaruhi besarnya risiko sistematis saham.

Di sisi lain, masih ada satu tantangan terberat dalam melaksanakan bisnis global yaitu fakta bahwa setiap negara menerapkan standar akuntansi yang berbeda untuk transaksi bisnis. Hal ini menjadi masalah tersendiri Pemecahan masalah perbedaan standar akuntansi di setiap negara adalah dengan dibentuknya standar akuntansi internasional yang disebut International Financial Reporting Standards (IFRS) (Walter et al: 2011, 6). IFRS atau International Financial Reporting Standards merupakan standar akuntansi internasional yang disusun oleh IASB yang digunakan untuk menyamakan standar, interpretasi, dan kerangka kerja dalam rangka penyusunan dan penyajian laporan keuangan di seluruh dunia.

Konvergensi IFRS di Indonesia merupakan proses penggantian secara bertahap standar akuntansi keuangan berbasis US GAAP menjadi standar 


\section{JURNAL NOMINAL / VOLUME III NOMOR 1 / TAHUN 2014}

akuntansi keuangan yang berbasis IFRS. Terdapat beberapa perbedaan mendasar antara US GAAP dan IFRS yaitu (1) IFRS menggunakan pengukuran setiap transaksi berdasarkan nilai wajar, terutama properti investasi, beberapa aset berwujud, aset keuangan dan aset biologis (Yona, 2012: 10), (2) IFRS didasarkan pada prinsip, sementara US GAAP lebih didasarkan pada aturan, (3) IFRS membuat asumsi bahwa pelaporan keuangan atas dasar akrual yaitu mencatat dampak dari transaksi bisnis ketika hal itu terjadi dan bukan ketika kas diterima atau dibayarkan. Perbedaan prinsip, aturan, dan kerangka konseptual antara IFRS dengan US GAAP menjadikan suatu masalah bagi perusahaan terutama perusahaan go public yang harus menyesuaikan laporan keuangan yang semula berbasiskan US GAAP menjadi berbasiskan IFRS.

Perubahan standar akuntansi keuangan di Indonesia yang berbasiskan IFRS akan mempengaruhi nilai leverage operasi, leverage keuangan dan leverage total. Menurut Konsenidis (2010: 144) Prinsip biaya historis yang diganti dengan nilai wajar akan mengubah penilaian setiap komponen data akuntansi yang disajikan dalam laporan keuangan. Penerapan nilai wajar sebagai dasar penilaian akan menutup adanya nilai intrinsik sehingga menguntungkan investor karena data akuntansi yang disajikan lebih relevan. Studi-studi empiris sebelumnya menyatakan bahwa adopsi IFRS secara mandatory berkaitan dengan likuiditas pasar dan penurunan biaya modal (cost of capital) perusahaan. Selain itu penggunaan praktik akuntansi yang sama di berbagai negara akan memudahkan investor dalam mendeteksi manajemen laba (Cahyati, 2011: 5). Barth et.al (2008) meneliti kualitas akuntansi sebelum dan sesudah diperkenalkannya IFRS menemukan bukti bahwa perusahaan yang menggunakan standar akuntansi keuangan internasional (IFRS) menunjukkan tingkat perataan laba dan manajemen laba yang lebih rendah dan mempunyai korelasi yang tinggi antara laba akuntansi dan harga saham dan return. Laba merupakan salah satu komponen yang dalam pengukuran leverage sehingga peningkatan kualitas laba akan menghasilkan nilai leverage yang sebenarnya. Return berkaitan erat dengan risiko, semakin tinggi return maka semakin tinggi risiko yang ditanggung, sehingga peningkatan nilai korelasi return karena konvergensi IFRS juga akan meningkatkan nilai korelasi risiko saham. Dari penjelasan di atas, dapat disimpulkan akan terdapat perbedaan nilai pengaruh leverage operasi, leverage keuangan, dan leverage total terhadap risiko sistematis saham.

Pemaparan di atas telah menjelaskan 


\section{JURNAL NOMINAL / VOLUME III NOMOR 1 / TAHUN 2014}

faktor-faktor yang mempengaruhi risiko sistematis saham. Untuk itu, penelitian ini akan memfokuskan pada faktor mikro (internal) dengan indikator leverage operasi, leverage keuangan, dan leverage total (kombinasi leverage operasi dan leverage keuangan) yang mempengaruhi risiko sistematis saham kategori perusahaan manufaktur yang terdaftar di Bursa Efek Indonesia sebelum dan sesudah konvergensi IFRS. Selain itu, penelitian ini juga akan meneliti perbedaan risiko sistematis saham sebelum dan sesudah konvergensi IFRS. Objek yang digunakan dalam penelitian ini adalah perusahaan manufaktur yang terdaftar di Bursa efek Indonesia (BEI) karena perusahaan jenis ini memiliki tingkat kerumitan dalam menentukan biaya suatu produk. Selain itu, perusahaan menufaktur dipandang memiliki risiko bisnis yang sangat tinggi (Brigham dan Houston, 2006: 11). Berdasarkan uraian di atas, judul penelitian ini "Pengaruh Leverage Operasi, Leverage Keuangan, dan Leverage Total Terhadap Risiko Sistematis Saham Pada Perusahaan manufaktur yang Terdaftar di Bursa Efek Indonesia Periode Sebelum dan Sesudah Konvergensi IFRS”.

\section{METODE PENELITIAN}

\section{Jenis Penelitian}

Penelitian ini merupakan penelitian kausal komparatif yaitu penelitian yang berusaha mengamati alasan atau penyebab terjadinya suatu fenomena yang diteliti. Jenis datanya, penelitian ini menggunakan data kuantitatif yaitu data yang berbentuk angka atau numerik.

\section{Populasi dan Sampel}

Populasi penelitian ini perusahaan manufaktur yang terdaftar di Bursa Efek Indonesia sebelum konvergensi IFRS periode 2010 sedangkan sesudah konvergensi IFRS periode 2012 sebanyak 136 perusahaan. Teknik pengambilan sampel yang akan digunakan dalam penelitian ini Sampling Purposive yaitu suatu metode pengambilan yang didapat 45 sampel.

Data, Intrumen, dan Teknik Pengumpulan

Teknik pengumpulan data dalam penelitian ini adalah dengan menggunakan metode dokumentasi dan studi pustaka. Jenis data yang digunakan dalam penelitian ini adalah data sekunder berupa laporan keuangan perusahaan tahun 2010 dan 2012. Sumber data penelitian ini diperoleh dengan melihat data dari laporan tahunan yang diterbitkan oleh website resmi BEI.

\section{Teknik Analisis Data}

1) Analisis Statistik Deskriptif Komparatif 


\section{JURNAL NOMINAL / VOLUME III NOMOR 1 / TAHUN 2014}

Statistik deskriptif merupakan statistik yang berfungsi untuk mendiskripsikan atau memberi gambaran terhadap obyek yang diteliti melalui data sampel atau populasi sebagaimana adanya, tanpa melakukan analisis dan membuat kesimpulan yang berlaku umum (Sugiyono, 2012: 29). Dalam statistik deskriptif ini akan dikemukan data mengenai mean, nilai maksimum, dan nilai minimum.

2) Uji Asumsi Klasik

a) Uji Normalitas

Uji normalitas bertujuan untuk menguji apakah dalam model regresi, variabel pengganggu atau residual memiliki distribusi normal (Ghozali, 2011: 160). Ada dua cara untuk mendeteksi apakah residual berdistribusi normal atau tidak yaitu dengan analisis grafik dan uji statistik. Metode yang lebih handal untuk melihat normalitas residual dengan uji statistik menggunakan uji Kolmogorov-Smirnov (K-S). Taraf signifikansi yang digunakan sebesar $5 \%$, jika nilai Asymp. Sig. (2-tailed) > 0,05 nilai data residual berdistribusi normal dan sebaliknya jika nilai Asymp. Sig. (2-tailed) $<0,05$ nilai data residual tidak berdistribusi normal.

b) Uji Linieritas

Uji linieritas dilakukan untuk mengetahui apakah hubungan antara variabel independen $(\mathrm{X})$ dengan variabel dependen (Y) bersifat linier (garis lurus).
Ada beberapa cara untuk menguji linieritas suatu data salah satunya menggunakan uji Lagrange Multiplier. Estimasi dengan uji ini bertujuan untuk mendapatkan nilai $\mathrm{c}^{2}$ hitung atau ( $\mathrm{n} \times \mathrm{R}^{2}$ ) yang dapat menentukan data tersebut linier atau tidak. Nilai $\mathrm{c}^{2}$ hitung $<\mathrm{c}^{2}$ tabel dapat disimpulkan bahwa model tersebut benar atau model linier (Ghozali, 2011: 169-170).

c) Uji Heteroskedastisitas

Uji heteroskedastisitas bertujuan untuk menguji dalam model regresi terjadi ketidaksamaan variance dari residual satu pengamatan ke pengamatan yang lain. Model regresi yang baik adalah yang homoskesdatisitas atau tidak terjadi heteroskedastisitas (Ghozali, 2011: 139). Cara untuk mendeteksi ada atau tidaknya heteroskedastisitas dengan melihat grafik plot antara nilai prediksi variabel dependen yaitu ZPRED dengan residualnya yaitu SRESID. Selain melihat grafik plot uji statistik yang dapat digunakan untuk mendeteksi ada tidaknya heteroskedastisitas adalah uji glejser. Uji ini dilakukan dengan meregresikan nilai absolut residual terhadap variabel independen (Gujarati, 2003) dalam (Ghozali, 2011).

3) Analisis Regresi Linier Sederhana

Regresi sederhana didasarkan pada hubungan fungsional ataupun kausal satu variabel independen dengan satu variabel dependen. Analisis regresi linier sederhana 
ini digunakan untuk menguji hipotesis pertama sampai hipotesis ketiga. Untuk melakukan perhitungan model analisis regresi linier sederhana tersebut, maka digunakan program software application SPSS 17.00 for windows. Uji hipotesis akan diuji berdasarkan koefisien regresi, koefisien determinasi, kemudian uji $\mathrm{t}$ dan melihat tingkat signifikansi.

4) Analisis Regresi Linier

Uji regresi linier yang digunakan untuk menguji hipotesis empat, lima dan enam merupakan uji regresi linier dengan kombinasi variabel dummy untuk membedakan periode sebelum dan sesudah konvergensi IFRS. Konvergensi IFRS menjadi variabel moderator atau $\mathrm{X}_{4}$ dalam penelitian ini. Untuk sebelum konvergensi IFRS dengan angka 0 dan untuk sesudah konvergensi IFRS dengan angka 1. Uji hipotesis diterima atau ditolak dapat dilihat dari nilai t hitung dan signifikansi.

5) Uji Beda t-test

Statistik parametris yang digunakan untuk menguji hipotesis komparatif rata-rata dua sampel bila datanya berbentuk interval atau ratio adalah menggunakan t-test (Sugiyono, 2012: 121). Hipotesis komparatif yang digunakan dalam penelitian ini adalah perbandingan risiko sistematis saham sebelum dan sesudah konvergensi IFRS.

\section{HASIL PENELITIAN \\ DAN \\ PEMBAHASAN \\ Statistik Deskriptif}

a. Risiko Sistematis Saham

Risiko sistematis saham merupakan risiko yang tidak dapat didiversifikasi yang disebabkan oleh pergerakan bursa saham secara umum dan mencerminkan adanya fakta bahwa sebagian besar saham secara sistematis akan terpengaruh oleh peristiwaperistiwa seperti perang, resesi, dan inflasi yang tercermin dari koefisien beta.

Tabel 1. Hasil Perhitungan Analisis Deskriptif Variabel Dependen (Risiko Sistematis Saham)

\begin{tabular}{|c|c|c|c|c|}
\hline Variabel & Min & Max & Mean & SD \\
\hline $\begin{array}{l}\text { Risiko Sistematis } \\
\text { Saham } 2010\end{array}$ & $-9,0757$ & 3,8145 & 0,0668 & 2,18637 \\
\hline $\begin{array}{l}\text { Risiko Sistematis } \\
\text { Saham } 2012\end{array}$ & $-5,8476$ & 6,3390 & 0,6874 & 2,35621 \\
\hline
\end{tabular}

Tabel 1 di atas menunjukkan bahwa variabel risiko sistematis saham memiliki nilai rata-rata (mean) sebesar 0,0668 pada tahun 2010 dan 0,6874 pada tahun 2012; nilai maksimum sebesar 3,8145 pada tahun 2010 dan 6,3390 pada tahun 2012; nilai minimum sebesar -9,0757 pada tahun 2010 dan $-5,8476$ pada tahun 2012; serta nilai standar deviasi sebesar 2,18637 pada tahun 2010 dan 2,35621 pada tahun 2012. Perusahaan yang memiliki risiko sistematis saham maksimum dalam penelitian ini adalah PT Indofood Sukses Makmur Tbk pada tahun 2010 dan PT Nusantara Inti 


\section{JURNAL NOMINAL / VOLUME III NOMOR 1 / TAHUN 2014}

Corpora Tbk pada tahun 2012, sedangkan perusahaan yang memiliki risiko sistematis saham minimum dalam penelitian ini adalah PT Pan Brothers Tbk pada tahun 2010 dan PT Berlina Tbk pada tahun 2012.

\section{b. Leverage Operasi}

Leverage operasi merupakan tingkat sejauh mana biaya-biaya tetap digunakan di dalam operasi sebuah perusahaan. Ukuran kuantitatif dari sensitivitas laba operasi perusahaan atas perubahan dalam penjualan disebut tingkat leverage operasional (degree of operating leverage-DOL). Besarnya leverage operasi dinyatakan dengan rumus persentase perubahan dalam Earning Before Interest and Tax (EBIT) dibagi persentase perubahan dalam output/penjualan.

Tabel 2. Hasil Perhitungan Analisis Deskriptif Variabel Leverage Operasi

\begin{tabular}{lllll}
\hline $\begin{array}{l}\text { Varia } \\
\text { bel }\end{array}$ & Min & Max & Mean & SD \\
\hline $\begin{array}{l}\text { Lever } \\
\text { age }\end{array}$ & & & & \\
$\begin{array}{l}\text { Opera } \\
\text { si }\end{array}$ & 5,4217 & 19,386 & 2,6696 & 4,7461 \\
2010 & & & & \\
$\begin{array}{l}\text { Lever } \\
\text { age }\end{array}$ & & & & \\
$\begin{array}{l}\text { Opera } \\
\text { si }\end{array}$ & 2,5941 & 7,1161 & 1,8942 & 2,0589 \\
2012 & & & & \\
\hline
\end{tabular}

Tabel 2 di atas menunjukkan bahwa variabel leverage operasi memiliki nilai rata-rata (mean) sebesar 2,6696 pada tahun 2010 dan 1,8942 pada tahun 2012; nilai maksimum sebesar 19.386 pada tahun 2010 dan 7.1161 pada tahun 2012; nilai minimum sebesar -5.4217 pada tahun 2010 dan 2.5941 pada tahun 2012; serta nilai standar deviasi sebesar 4,7461 pada tahun 2010 dan 2,0589 pada tahun 2012. Perusahaan yang memiliki nilai leverage operasi maksimum dalam penelitian ini adalah PT Alumindo Light Metal Industry Tbk pada tahun 2010 dan PT Ultrajaya Milk Industry and Trading Company Tbk pada tahun 2012, sedangkan perusahaan yang memiliki leverage operasi minimum dalam penelitian ini adalah PT Japfa Comfeed Indonesia Tbk pada tahun 2010 dan PT Nusantara Inti Corpora Tbk pada tahun 2012.

\section{c. Leverage Keuangan}

Leverage Keuangan merupakan sampai sejauh mana sekuritas dengan pendapatan tetap (utang dan saham preferen) digunakan dalam struktur modal sebuah perusahaan. Ukuran kuantitatif untuk sensitivitas EPS perusahaan terhadap perubahan dalam laba operasional perusahaan adalah DFL (degree of financial leverage). Besarnya leverage keuangan dinyatakan dengan rumus perubahan persentase dalam Earning per Share (EPS) dibagi perubahan persentase dalam Earning Before Interest and Tax (EBIT).

Leverage keuangan memiliki nilai ratarata (mean) sebesar 1,3688 pada tahun 2010 dan 0,7816 pada tahun 2012; nilai maksimum sebesar 8,2988 pada tahun 2010 


\section{JURNAL NOMINAL / VOLUME III NOMOR 1 / TAHUN 2014}

dan 15,0262 pada tahun 2012; nilai minimum sebesar $-1,5648$ pada tahun 2010 dan $-6,3336$ pada tahun 2012; serta nilai standar deviasi sebesar 1,8380 pada tahun 2010 dan 2,8403 pada tahun 2012. Perusahaan yang memiliki nilai leverage keuangan maksimum dalam penelitian ini adalah PT Primarindo asia Infrastructure Tbk pada tahun 2010 dan PT Surya Toto Indonesia Tbk pada tahun 2012, sedangkan perusahaan yang memiliki nilai leverage keuangan minimum dalam penelitian ini adalah PT Darya Varia Laboratoria Tbk pada tahun 2010 dan PT Kalbe Farma Tbk pada tahun 2012.

\section{d. Leverage Total}

Leverage Total merupakan pengaruh dari menggabungkan leverage keuangan dengan leverage operasi. Ukuran kuantitatif yang digunakan untuk leverage total disebut degree of total leverage-DTL. Besarnya leverage total dinyatakan dengan rumus perubahan persentase dalam EPS dibagi perubahan persentase dalam penjualan

Tabel 3. Hasil Perhitungan Analisis Deskriptif Variabel Leverage Total

\begin{tabular}{llllll}
\hline Variabel & Range & Min & Max & Mean & SD \\
\hline $\begin{array}{l}\text { Leverage } \\
\text { Total }\end{array}$ & 23,3923 & - & & & \\
2010 & & 7,9870 & 15,4053 & 2,3791 & 4,8912 \\
Leverage & & & & & \\
Total & 16,8408 & - & & & \\
2012 & & 5,0962 & 11,7446 & 2,0188 & 3,4056 \\
\hline
\end{tabular}

Tabel 3 di atas menunjukkan bahwa variabel leverage total memiliki nilai ratarata (mean) sebesar 2,3791 pada tahun 2010 dan 2.0188 pada tahun 2012; nilai maksimum sebesar 15,4053 pada tahun 2010 dan 11,7446 pada tahun 2012; nilai minimum $-7,9870$ pada tahun 2010 dan 5,0962 pada tahun 2012; serta nilai standar deviasi sebesar 4,89128 pada tahun 2010 dan 3,4056 pada tahun 2012. Perusahaan yang memiliki nilai leverage total maksimum dalam penelitian ini adalah PT Malindo Feedmill Tbk pada tahun 2010 dan PT Budi Acid Jaya Tbk pada tahun 2012, sedangkan perusahaan yang memiliki risiko sistematis saham minimum dalam penelitian ini adalah PT Japfa Comfeed Indonesia Tbk pada tahun 2010 dan PT Surya Toto Indonesia Tbk pada tahun 2012.

\section{Hasil Uji Asumsi Klasik}

a. Uji Normalitas

Salah satu alat uji normalitas adalah dengan nilai Asymp. Sig. (2-tailed) pada Uji Kolmogorov-Smirnov. Berdasarkan data yang telah diolah menggunakan program SPSS versi 17.0, maka hasil pengolahan adalah sebagai berikut:

Tabel 4. Hasil Uji Normalitas (Uji

\begin{tabular}{lc}
\multicolumn{2}{l}{ Kolmogorov-Smirnov) } \\
\hline Periode & Asymp. Sig. $(2$-tailed $)$ \\
\hline 2010 & 0,704 \\
2012 & 0,280 \\
\hline
\end{tabular}




\section{JURNAL NOMINAL / VOLUME III NOMOR 1 / TAHUN 2014}

Berdasarkan Tabel 4 di atas dapat dilihat nilai Asymp. Sig. (2-tailed) KolmogorovSmirno sebelum konvergensi IFRS sebesar 0,704 dan nilai Asymp. Sig. (2-tailed) Kolmogorov-Smirno sesudah konvergensi IFRS sebesar 0,280, nilai Asymp. Sig. (2tailed) Kolmogorov-Smirno kedua tahun tersebut melebihi dari nilai $\alpha=0,05$ yang menunjukkan data tersebut berdistribusi normal.

\section{b. Uji Linieritas}

Ada beberapa cara untuk menguji linieritas suatu data salah satunya menggunakan uji Lagrange Multiplier. Hasil uji menggunakan SPSS versi 17.0 sebagai berikut:

Tabel 5. Hasil Uji Linieritas (Uji Lagrange Multiplier)

\begin{tabular}{ll}
\hline Periode & R Square \\
\hline 2010 & 0,010 \\
2012 & 0,124 \\
\hline
\end{tabular}

Tabel 5 menunjukkan adanya nilai $\mathrm{R}$ square. Chi square dapat dihitung dengan mengalikan $\mathrm{R}$ square dan $\mathrm{n}$ atau jumlah data yang dijadikan sampel. Jadi, chi square $2010=0,010 \times 45=0,45$ dan chi square $2012=0,124 \times 45=5,58$. Kemudian nilai chi square ini dibandingkan dengan nilai chi tabel. Nilai chi tabel 61,656 lebih besar daripada nilai chi hitung 0,45 dan 5,58. Jadi, dapat disimpulkan bahwa data penelitian ini memenuhi asumsi uji linearitas. c. Uji Heteroskedastisitas

Uji heteroskedastisitas dapat dideteksi dengan uji Glejser. Uji Glejser dilakukan dengan cara meregresikan antara variabel independen dengan nilai absolut residualnya.

Tabel 6. Hasil Uji Heteroskedastisitas

\begin{tabular}{|c|c|c|}
\hline Variabel & $\begin{array}{l}\text { Sig. } \\
(2010)\end{array}$ & $\begin{array}{l}\text { Sig. } \\
(2012)\end{array}$ \\
\hline (Constant) & 0,000 & 0,000 \\
\hline $\begin{array}{l}\text { Leverage } \\
\text { Operasi }\end{array}$ & 0,584 & 0,536 \\
\hline $\begin{array}{l}\text { Leverage } \\
\text { Keuangan }\end{array}$ & 0,371 & 0,647 \\
\hline Leverage Total & 0,571 & 0,125 \\
\hline
\end{tabular}

Berdasarkan tabel 6 di atas dapat dilihat bahwa nilai signifikansi lebih besar dari 0,05, maka dapat disimpulkan bahwa dalam model regresi ini tidak terjadi heteroskedastisitas.

\section{Hasil Uji Hipotesis}

a. Pengaruh Leverage Operasi Terhadap Risiko Sistematis Saham Sebelum dan Sesudah Konvergensi IFRS

Hasil uji regresi sederhana yang telah diolah menggunakan program SPSS versi 17.0 sebagai berikut: 


\section{JURNAL NOMINAL / VOLUME III NOMOR 1 / TAHUN 2014}

Tabel 7. Ringkasan Hasil Uji Regresi Sederhana Leverage Operasi terhadap Risiko Sistematis Saham

\begin{tabular}{lcccccc}
\hline & \multirow{6}{*}{ Kons } & Koef & \multicolumn{2}{c}{ Nilai t } & & \\
Variabel & & & $\mathrm{t}_{\text {hitung }}$ & $\mathrm{t}_{\text {tabel }}$ & & $\mathrm{r}^{2}$ \\
& & & & & \\
\hline Leverage & 0,132 & - & - & 1,679 & 0,730 & 0,003 \\
Operasi 2010 & & 0,024 & 0,347 & & & \\
Leverage & 0,779 & - & - & & & \\
Operasi 2012 & & 0,048 & 0,278 & 1,679 & 0,782 & 0,002 \\
\hline
\end{tabular}

b. Pengaruh Leverage Keuangan terhadap Risiko Sistematis Saham Sebelum dan Sesudah Konvergensi IFRS

Hasil uji regresi sederhana yang telah diolah menggunakan program SPSS versi 17.0 sebagai berikut:

Tabel 8. Ringkasan Hasil Uji Regresi Leverage Keuangan terhadap Risiko Sistematis Saham

Dari hasil tersebut, dapat dibuat persamaan regresi sebagai berikut $\mathrm{Y}(2010)$ $=0,132-0,024 \mathrm{X}_{1}$ dan $\mathrm{Y}(2012)=0,779-$ $0,048 \mathrm{X}_{1}$. Berdasarkan tabel $7 \mathrm{di}$ atas, dapat dilihat bahwa nilai koefisien

determinasi $\left(\mathrm{r}^{2}\right)$ menunjukkan bahwa risiko sistematis saham perusahaan manufaktur yang terdaftar di BEI periode 2010 dipengaruhi oleh $0,3 \%$ variabel leverage operasi dan risiko sistematis saham periode 2012 dipengaruhi oleh $0,2 \%$ variabel leverage operasi. Nilai t hitung (mutlak) lebih kecil daripada t tabel $(0,347<1,678)$ untuk tahun 2010 dan $(0,278<1,678)$ untuk tahun 2012. Nilai sig sebesar 0,730 tahun 2010 dan 0,782 tahun lebih besar dari nilai $\alpha=5 \%$. Berdasarkan uji hipotesis tersebut dengan melihat nilai koefisien regresi, t-hitung dan signifikansi maka hipotesis pertama yang menyatakan "Leverage operasi berpengaruh positif terhadap risiko sistematis saham sebelum dan sesudah konvergensi IFRS" ditolak.

\begin{tabular}{|c|c|c|c|c|c|c|}
\hline \multirow[b]{2}{*}{ Variabel } & \multirow[b]{2}{*}{ Kons } & \multirow[b]{2}{*}{ Koef } & \multicolumn{2}{|c|}{ Nilai t } & \multirow{2}{*}{$\mathrm{r}^{2}$} & \multirow[b]{2}{*}{ Sig } \\
\hline & & & $t_{\text {hitung }}$ & $\mathrm{t}_{\text {tabel }}$ & & \\
\hline Leverage & & & & & & \\
\hline $\begin{array}{l}\text { Keuangan } \\
2010\end{array}$ & $0, \overline{067}$ & 0,098 & 0,540 & 1,679 & 0,007 & 0,592 \\
\hline $\begin{array}{l}\text { Leverage } \\
\text { Keuangan } \\
2012\end{array}$ & 0,878 & $0, \overline{244}$ & 2, $\overline{0} 21$ & 1,679 & 0,087 & 0,050 \\
\hline
\end{tabular}

Dari hasil tersebut, dapat dibuat persamaan regresi sebagai berikut: Y(2010) $=-0,067+0,098 X_{2}$ dan $\mathrm{Y}(2012)=0,878-$ $0,244 X_{2}$. Nilai koefisien determinasi $\left(r^{2}\right)$ menunjukkan bahwa risiko sistematis saham periode 2010 dipengaruhi oleh 0,7\% variabel leverage keuangan. Nilai sig sebesar 0,592 tahun 2010 dan 0,050 tahun 2012 pada tabel 8 di atas menunjukkan bahwa pengaruh leverage keuangan terhadap risiko sistematis saham sebelum dan sesudah konvergensi IFRS tidak signifikan. Berdasarkan uji hipotesis tersebut dengan melihat nilai koefisien regresi, t-hitung dan signifikansi maka hipotesis yang menyatakan "Leverage keuangan berpengaruh positif terhadap 


\section{JURNAL NOMINAL / VOLUME III NOMOR 1 / TAHUN 2014}

risiko sistematis saham sebelum dan sesudah konvergensi IFRS" ditolak.

c. Pengaruh Leverage Total terhadap Risiko Sistematis Saham Sebelum dan

Sesudah Konvergensi IFRS

Hasil uji regresi sederhana yang telah diolah menggunakan program SPSS versi 17.0 sebagai berikut:

Tabel 9. Ringkasan Hasil Uji Regresi Sederhana Leverage Total terhadap Risiko Sistematis Saham

\begin{tabular}{lcccccc}
\hline Variabel & Kons & Koef & \multicolumn{2}{c}{ Nilai $\mathrm{S}$} & $\mathrm{r}^{2}$ \\
& & & $\mathrm{t}_{\text {hitung }}$ & $\mathrm{t}_{\text {tabel }}$ & & \\
\hline $\begin{array}{l}\text { Leverage } \\
\text { Total }\end{array}$ & 0,046 & 0,009 & 0,129 & 1,679 & 0,898 & 0,000 \\
2010 & & & & & & \\
$\begin{array}{l}\text { Leverage } \\
\text { Total }\end{array}$ & 0,527 & 0,080 & 0,760 & 1,679 & 0,451 & 0,013 \\
2012 & & & & & & \\
\hline
\end{tabular}

Dari hasil tersebut, dapat dibuat persamaan regresi sebagai berikut: $\mathrm{Y}(2010)$ $=0,046+0,009 X_{3}$ dan $\mathrm{Y}(2012)=0,527+$ $0,080 X_{3}$. Berdasarkan tabel 11 di atas, dapat dilihat bahwa nilai koefisien determinasi $\left(\mathrm{r}^{2}\right)$ menunjukkan bahwa risiko sistematis saham perusahaan manufaktur yang terdaftar di BEI periode 2010 tidak dipengaruhi oleh variabel leverage total dan risiko sistematis saham periode 2012 dipengaruhi oleh 1,3\% variabel leverage total. Nilai sig sebesar 0,898 tahun 2010 dan 0,451 tahun 2012 di atas menunjukkan bahwa pengaruh leverage total terhadap risiko sistematis saham sebelum dan sesudah konvergensi IFRS tidak signifikan. Berdasarkan uji hipotesis tersebut dengan melihat nilai koefisien regresi, t-hitung dan signifikansi maka hipotesis ketiga "Leverage total berpengaruh positif terhadap risiko sistematis saham sebelum dan sesudah konvergensi IFRS" ditolak.

d. Terdapat Perbedaan Pengaruh Leverage Operasi terhadap Risiko Sistematis Saham Sebelum dan Sesudah Konvergensi IFRS

Hasil uji regresi yang telah diolah menggunakan program SPSS versi 17.0 adalah sebagai berikut:

Tabel 10. Hasil Uji Regresi Perbedaan Pengaruh Leverage Operasi terhadap Risiko Sistematis

\begin{tabular}{llll}
\hline & Koefisien & $\mathrm{t}_{\text {hitung }}$ & Sig. \\
\hline Constant & 0,132 & 0,335 & 0,739 \\
Leverage Operasi & $-0,024$ & $-0,334$ & 0,740 \\
IFRS & 0,647 & 1,059 & 0,293 \\
Perbedaan Pengaruh & $-0,024$ & $-0,132$ & 0,896 \\
\hline
\end{tabular}

Berdasarkan Tabel 10 di atas, dapat dibuat persamaan regresi sebagai berikut : Y $=0,132-0,024 X_{1}+0,647 X_{4}-0,024 X_{1} X_{4}$. Nilai t hitung (mutlak) lebih kecil daripada t tabel $(0,132<1,662)$. Nilai sig sebesar 0,896 lebih besar dari nilai $\alpha=5 \%$. Berdasarkan uji hipotesis tersebut dengan melihat nilai t-hitung dan signifikansi maka hipotesis keempat yang menyatakan "terdapat perbedaan pengaruh leverage operasi terhadap risiko sistematis saham 
sebelum dan sesudah konvergensi IFRS" ditolak.

e. Terdapat Perbedaan Pengaruh Leverage Keuangan terhadap Risiko Sistematis Saham Sebelum dan Sesudah Konvergensi IFRS

Hasil uji regresi yang telah diolah menggunakan program SPSS versi 17.0 adalah sebagai berikut:

Tabel 11. Hasil Uji Regresi Perbedaan Pengaruh Leverage Keuangan terhadap Risiko Sistematis

\begin{tabular}{llll}
\hline & Koefisien & $\mathrm{t}_{\text {hitung }}$ & Sig. \\
\hline Constant & $-0,067$ & $-0,160$ & 0,873 \\
Leverage Keuangan & 0,098 & 0,531 & 0,597 \\
IFRS & 0,945 & 1,740 & 0,085 \\
Perbedaan Pengaruh & $-0,342$ & $-1,562$ & 0,122 \\
\hline
\end{tabular}

Berdasarkan Tabel 11 di atas, dapat dibuat persamaan regresi sebagai berikut : $\mathrm{Y}$ $=-0,067+0,098 X_{2}+0,945 X_{4}-0,342 X_{2} X_{4}$. Nilai thitung (mutlak) lebih kecil daripada $t$ tabel $(1,562<1,662)$. Nilai sig sebesar 0,122 lebih besar dari nilai $\alpha=5 \%$. Berdasarkan uji hipotesis tersebut dengan melihat nilai koefisien regresi, t-hitung dan signifikansi maka hipotesis kelima yang menyatakan "terdapat perbedaan pengaruh leverage keuangan terhadap risiko sistematis saham sebelum dan sesudah konvergensi IFRS" ditolak.

f. Terdapat Perbedaan Pengaruh Leverage Total terhadap Risiko Sistematis Saham Sebelum dan Sesudah Konvergensi IFRS
Hasil uji regresi yang telah diolah menggunakan program SPSS versi 17.0 adalah sebagai berikut:

Tabel 12. Hasil Uji Regresi Perbedaan Pengaruh Leverage Total terhadap Risiko Sistematis Saham

\begin{tabular}{llll}
\hline & Koefisien & $\mathrm{t}_{\text {hitung }}$ & Sig. \\
\hline Constant & 0,046 & 0,121 & 0,904 \\
Leverage Total & 0,009 & 0,124 & 0,901 \\
IFRS & 0,481 & 0,873 & 0,385 \\
Perbedaan Pengaruh & 0,071 & 0,574 & 0,568 \\
\hline
\end{tabular}

Berdasarkan Tabel 12 di atas, dapat dibuat persamaan regresi sebagai berikut : Y $=0,046+0,009 X_{3}+0,481 X_{4}+0,071 X_{3} X_{4}$. Nilai t hitung lebih kecil daripada t tabel $(0,574<1,662)$. Nilai sig sebesar 0,568 lebih besar dari nilai $\alpha=5 \%$. Berdasarkan uji hipotesis tersebut dengan melihat nilai koefisien regresi, t-hitung dan signifikansi maka hipotesis keenam yang menyatakan "terdapat perbedaan pengaruh levearage total terhadap risiko sistematis saham sebelum dan sesudah konvergensi IFRS" ditolak.

g. Terdapat Perbedaan Tingkat Risiko Sistematis Saham antara Sebelum Konvergensi IFRS dengan Sesudah Konvergensi IFRS

Hasil uji beda t-test yang telah diolah menggunakan program SPSS versi 17.0 adalah sebagai berikut: 
Tabel 13. Hasil Uji t-test

\begin{tabular}{lcl}
\hline & $\mathrm{t}_{\text {hitung }}$ & Sig. (2-tailed) \\
\hline $\begin{array}{l}\text { Perbedaan Risiko } \\
\text { Sistematis Saham }\end{array}$ & $-1,273$ & 0,210 \\
\hline
\end{tabular}

Berdasarkan Tabel 13 di atas, nilai $\mathrm{t}$ hitung (mutlak) lebih kecil daripada t tabel $(1,273<1,987)$. Nilai sig sebesar 0,210 lebih besar dari nilai $\alpha=5 \%$. Berdasarkan uji hipotesis tersebut dengan melihat nilai thitung dan signifikansi maka hipotesis ketujuh yang menyatakan "terdapat perbedaan risiko sistematis saham sebelum dan sesudah konvergensi IFRS" ditolak.

\section{SIMPULAN DAN SARAN}

\section{Simpulan}

Penelitian ini memberikan beberapa kesimpulan sebagai berikut:

a. Leverage operasi berpengaruh negatif dan tidak signifikan terhadap risiko sistematis saham sebelum dan sesudah konvergensi IFRS. Hal ini dapat dilihat dari nilai koefisien regresi yang bernilai negatif yaitu $-0,024$ pada tahun 2010 dan -0,048 pada tahun 2012. Nilai signifikansi leverage operasi terhadap risiko sistematis saham sebelum dan sesudah konvergensi IFRS lebih besar daripada nilai signifikansi $\alpha=5 \%$ yaitu $(0,730>0,05)$ pada tahun 2010 dan $(0,782>0,05)$ pada tahun 2012.

b. Leverage keuangan berpengaruh positif dan tidak signifikan terhadap risiko sistematis saham sebelum konvergensi IFRS sedangkan leverage keuangan berpengaruh negatif dan tidak signifikan terhadap risiko sistematis saham sesudah konvergensi IFRS. Hal ini dapat dilihat dari nilai koefisien regresi yang bernilai positif yaitu 0,098 pada tahun 2010 dan bernilai negatif yaitu $-0,244$ pada tahun 2012. Nilai signifikansi leverage keuangan terhadap risiko sistematis saham tahun 2010 IFRS lebih besar daripada nilai signifikansi $\alpha=5 \%$ yaitu $(0,592>0,05)$ dan nilai signifikansi tahun 2012 sama dengan nilai signifikansi $\alpha=5 \%$ yaitu $(0,05=0,05)$.

c. Leverage total tidak berpengaruh terhadap risiko sistematis saham sebelum konvergensi IFRS dan variabel leverage total berpengaruh positif dan tidak signifikan terhadap risiko sistematis saham sesudah konvergensi IFRS. Hal ini dapat dilihat dari nilai koefisien regresi yang bernilai positif yaitu 0,009 tahun 2010 dan 0,080 tahun 2012. Nilai R square 0,000 tahun 2010 menunjukkan bahwa leverage total tidak berpengaruh terhadap risiko sistematik saham dan nilai $\mathrm{R}$ square 0,013 tahun 2012 menunjukkan bahwa leverage total berpengaruh sebesar $1,3 \%$ terhadap risiko sistematik saham. Nilai signifikansi leverage total terhadap risiko sistematis saham sebelum dan 


\section{JURNAL NOMINAL / VOLUME III NOMOR 1 / TAHUN 2014}

sesudah konvergensi IFRS lebih besar daripada nilai signifikansi $\alpha=5 \%$ yaitu $(0,898>0,05)$ tahun 2010 dan $(0,451>$ 0,05) tahun 2012.

d. Tidak terdapat perbedaan pengaruh leverage operasi terhadap risiko sistematis saham sebelum dan sesudah konvergensi IFRS. Hal ini dapat dilihat dari nilai $\mathrm{t}$ hitung (mutlak) lebih kecil daripada nilai $\mathrm{t}$ tabel $(0,132<1,662)$ pada tingkat signifikansi 5\%. Selain itu, nilai signifikansi lebih besar daripada nilai signifikansi $\alpha=5 \% \quad(0,896>$ 0,005).

e. Tidak terdapat perbedaan pengaruh leverage keuangan terhadap risiko sistematis saham sebelum dan sesudah konvergensi IFRS. Hal ini dapat dilihat dari nilai t hitung (mutlak) lebih kecil daripada nilai $\mathrm{t}$ tabel $(1,562<1,662)$ pada tingkat signifikansi 5\%. Selain itu, nilai signifikansi lebih besar daripada nilai signifikansi $\alpha=5 \% \quad(0,122>$ 0,005).

f. Tidak terdapat perbedaan pengaruh leverage total terhadap risiko sistematis saham sebelum dan sesudah konvergensi IFRS. Hal ini dapat dilihat dari nilai $\mathrm{t}$ hitung lebih kecil daripada nilai $t$ tabel $(0,574<1,662)$ pada tingkat signifikansi $5 \%$. Selain itu, nilai lebih besar daripada nilai signifikansi $\alpha=5 \% \quad(0,568>$ 0,005). g. Tidak terdapat perbedaan tingkat risiko sistematis saham antara sebelum dengan sesudah konvergensi IFRS. Hal ini ditunjukkan dengan nilai $\mathrm{t}$ hitung (mutlak) uji beda t-test lebih kecil daripada $\mathrm{t}$ tabel yaitu $(1,273<1,987)$ dan nilai signifikansi lebih besar daripada nilai signifikansi $\alpha=5 \%(0,210$ $>0,005)$.

\section{Saran}

Penelitian ini menghasilkan beberapa saran sebagai berikut:

a. Bagi Perusahaan

Perusahaan hendaknya memberikan laporan keuangan yang lebih baik dan sesuai dengan standar akuntansi keuangan yang diterapkan di Indonesia sehingga laporan keuangan menunjukkan nilai yang sebenarnya sehingga mampu menjaga kepercayaan investor untuk berinvestasi di perusahaan.

b. Bagi Investor

Investor hendaknya memahami semua informasi yang relevan yang tersedia di pasar modal melalui laporan keuangan yang dipublikasikan perusahaan. Investor juga harus memperhatikan faktorfaktor internal seperti leverage operasi, leverage keuangan, leverage total dan perubahan standar akuntansi keuangan yang akan 
memperbesar risiko sistematis saham sehingga merugikan investor.

c. Bagi Peneliti Selanjutnya

1) Peneliti sebaiknya menambah jumlah sampel yang diteliti.

2) Peneliti sebaiknya memperpanjang periode penelitian agar dapat diperoleh hasil penelitian yang lebih baik dan akurat tidak hanya satu tahun untuk sebelum dan sesudah konvergensi IFRS.

3) Peneliti menambah variabel lain yang mempengaruhi risiko sistematis saham.

\section{DAFTAR PUSTAKA}

Ari Dewi Cahyati. (2011). "Peluang Manajemen Laba Pasca Konvergensi IFRS: Sebuah Tinjauan Teoritis dan Empiris". Jurnal Riset Akuntansi dan Komputerisasi Akuntansi (Vol 2 Nomor 1 tahun 2011). Hlm. 1-6.

Bambang Sudiyatno dan Cahyani Nuswandhari. (2009). "Peran Beberapa Indikator Ekonomi Dalam Mempengaruhi Risiko Sistematik Perusahaan Manufaktur di Bursa Efek Indonesia Jakarta". Jurnal Dinamika Keuangan dan Perbankan (Vol 1 Nomor 2 tahun 2009). ISSN :19794878. Hlm. $66-81$.
Barth, M.E., W.R. Landsman and Lang M.H. (2008). "International Accounting Standard and Accounting Quality”. Journal of Accounting Research, 46, 467-498.

Brigham, Eugene F. \& Houston, Joel F.. (2006). Dasar-dasar Manajemen Keuangan. Edisi 10. Buku 2. (Alih Bahasa: Ali Akbar Yulianto). Jakarta: Salemba Empat.

(2006). Dasar-dasar Manajemen Keuangan. Edisi 10. Buku 1. (Alih Bahasa: Ali Akbar Yulianto). Jakarta: Salemba Empat.

(2012). Dasar-dasar Manajemen Keuangan. Edisi 11. Buku 1. (Alih Bahasa: Ali Akbar Yulianto). Jakarta: Salemba Empat.

Harrison, Walter T. et al. (2011). Akuntansi

Keuangan: International Financial Reporting Standards (IFRS). Edisi 8. Buku 1. (Alih Bahasa: Gina Gania). Jakarta: Erlangga.

Imam Ghozali. (2011). Aplikasi Analisis Multivariate dengan Program IBM SPSS 19. Semarang: Badan Penerbit Universitas Diponegoro.

Jogiyanto Hartono. (2010). Teori Portofolio dan Analisis Investasi. Edisi Ketujuh. Yogyakarta: BPFE. 
Keown, Arthur J. et al. (2005). Manajemen

Keuangan : Prinsip dan Penerapan.

Edisi 10. Buku 1. (Alih Bahasa: Marcus

Prihminto Widodo, M.A). Jakarta: PT

Macanan Jaya Cemerlang.

Konsenidis, Dimitrios V, et al. (2010).

"Value Relevance of Accounting

Information in the Pre- and Post-IFRS

Accounting Periods". Jurnal Akuntansi

(Volume XIII, Issue 1). European

Research Studies.

Ratu Nurul Qomariah. (2013). “Dampak

Konvergensi IFRS terhadap Manajemen

Laba dengan Struktur Kepemilikan

Manajerial sebagai Variabel Moderating

(Studi Empiris pada Perusahaan

Manufaktur yang Terdaftar di Bursa

Efek Indonesia Tahun 2009-2012)".

Skripsi. Universitas Diponegoro

Semarang.

Sugiyono. (2011). Metode Penelitian

Kuantitatif, Kualitatif, dan Kombinasi

(Mixed Methods). Bandung: Alfabeta.

(2012). Statistika untuk

Penelitian. Edisi 21. Bandung: Alfabeta.

Van Horne, James C \& Wachowicz, John

M. (2007). Prinsip-Prinsip Manajemen

Keuangan. Edisi 12. Buku 2. (Alih

Bahasa: Dewi Fitriasari, M.Si \& Deny

Arnis Kwary, M.Hum). Jakarta:

Salemba Empat.

Yona Octiani Lestari. (2012). "Konvergensi

International Financial Reporting
Standards (IFRS) dan Manajemen Laba

di Indonesia”. Jurnal Akuntansi.

Universitas Islam Negeri Maulana Malik

Ibrahim Malang.

Yusuf Wibisono. (2005). Metode Statistika.

Edisi 1. Yogyakarta: Gadjah Mada University Press. 